\title{
EFEKTIFITAS PENERAPAN PENGENDALIAN INTERN (INTERNAL CONTROL) TERHADAP PENGUKURAN KINERJA DINAS PENDAPATAN DAERAH KABUPATEN MINAHASA TENGGARA PROVINSI SULAWESI UTARA
}

\author{
Pancisto Patik \\ Jantje Tinangon \\ Victorina Z. Tirayoh \\ Fakultas Ekonomi Dan Bisnis, Jurusan Akuntansi \\ Universitas Sam Ratulangi, Manado \\ Email :pancisto.p@yahoo.com \\ jantjetinangon447@gmail.com \\ vtirayoh@yahoo.com
}

\begin{abstract}
The system of internal control is a process that is integral to the actions and activities carried out on an ongoing basis by management and all employees to provide reasonable assurance on the achievement of organizational goals through effective and efficient, the reliability of financial statements, safeguarding state assets, and compliance with laws -invitation. The purpose of this study was to determine the effectiveness of the implementation of internal control of the performance of the Department of Revenue Southeast Minahasa Regency. This research method is descriptive research. Based on the results of research and discussion can be seen that the Internal Control System (Internal Control) on the performance of the Department of Revenue Southeast Minahasa Regency North Sulawesi province has been run "effective" because it was done separation of duties and responsibilities are clear, the forms that were used in the reception area already contains information that is reliable, and the achievement of revenue targets revenue in 2015 has been effective, while the main tasks in the organization are based on Government Regulation No. 60 of 2008 concerning the Government Internal Control System (SPIP) is adequate.
\end{abstract}

Keyword: PAD Admission Control Procedures and Control Organization Department of Revenue Southeast Minahasa Regency.

\section{PENDAHULUAN}

\section{Latar belakang}

Perkembangan perusahaan baik milik negara maupun swasta selaku pelaku ekonomi telah terorganisir dan tidak terlepas dari hukum ekonomi dan prinsip dasar perusahaan pada umumnya. Dengan perkembangan perusahaan di era globalisasi ini semakin mempertajam adanya persaingan sehingga memerlukan adanya pemikiran yang kritis dalam pengelolaan sumber dana dan daya yang ada. Perusahaan dituntut untuk selalu profesional dalam menjalankan kegiatan operasionalnya agar dapat bersaing dengan para pesaingnya dengan menjalankan pengendalian (control) yang baik dalam organisasinya agar tercipta kegiatan operasional perusahaan yang efisien dan efektif.Karyawan dan manajer juga dituntut untuk melakukan pekerjaanya secara profesional sehingga perusahaan dapat berjalan dan bertahan ditengah ketatnya persaingan.Dalam berbagai hal karyawan dan manager mempunyai keterbatasan untuk melakukan kesalahan sehingga dibutuhkan sebuah sistem yang dapat berfungsi sebagai alat pengendalian, pengawasan dan pengevaluasian terhadap aktivitas usaha agar tidak terjadi penyelewengan yang mengakibatkan kerugian bagi perusahaan. Salah satu permasalahan yang sering terjadi pada perusahaan baik milik negara maupun swasta dalam melaksanakan internal control atau pengawasan internal adalah pengawasan tersebut tidak sesuai dengan pedoman tujuan dan unsur yang terdapat dalam internal control.Dinas Pendapatan Daerah (DISPENDA) Kabupaten Minahasa Tenggara adalah objek yang diambil dalam penelitian ini. 
Dinas Pendapatan Daerah Kabupaten Minahasa Tenggara adalah instansi yang berada dibawah Pemerintahan Kabupaten Minahasa Tenggara, yang memiliki tugas dantanggung jawab dalam pemungutan pendapatan daerah melalui pengkoordinasian dan pemungutan pajak, retribusi, bagi hasil pajak, dana perimbangan dan lain sebagainya. Untuk menjalankan tugas pokok dan fungsi Dispenda Kabupaten Minahasa Tenggara tersebut diperlukan adanya Sistem Pengendalian Internal (Internal Control Systems) yang baik. Salah satu unsur Sistem Pengendalian Internal pada Dispenda Kabupaten Minahasa Tenggara yaitu unsur struktur organisasi yang sebaiknya memisahkan fungsi operasional, penerimaan, penyimpanan, dan pencatatan, agar dengan pemisahan fungsi tersebut dapat menghindari kecurangan operasional guna peningkatan pendapatan daerah.

Memperhatikan tugas pokok dari Dinas Pendapatan Daerah Kabupaten Minahasa Tenggara antara lain: meningkatkan kualitas sumber daya aparatur dan organisasi, meningkatkatkan kesadaran wajib pajak, meningkatkan kualitas dan pengelolaan pendapatan daerah. Dengan demikian Dinas Pendapatan Daerah Kabupaten Minahasa Tenggara harus bisa mengoptimalkan pengawasan internal guna mencapai tujuan dalam pelaksanaan tugas pokok tersebut secara efektif dan efisien, sehingga dapat terwujud otonomi daerah yang nyata dan bertanggung jawab.

\section{Tujuan Penelitan}

Untuk mengetahui bagaimana sistem pengendalian intern pada Dinas Pendapatan Daerah Kabupaten Minahasa Tenggara telah berjalan efektif.

\section{TINJAUAN PUSTAKA}

\section{Pengertian Akuntansi}

Pengertian akuntansi menurut Ismail (2010:2), akuntansi dapat diartikan sebagai seni dalam melakukan pencatatan, penggolongan, dan pengikhtisaran, yang mana hasil akhirnya tercipta sebuah seluruh aktivitas keuangan perusahaan.Tujuan akuntansi yang digambarkan dalam laporan keuangan adalah untuk memberikan informasi yang bermanfaat untuk pengambilan keputusan para pemakai.

\section{Pengertian Akuntansi Pemerintahan}

Menurut Indra Bastian (2010:138) akuntansi pemerintahan adalah prinsip-prinsip akuntansi yang ditetapkan dalam menyusun dan menyajikan laporan keuangan pemerintah.Menurut Abdul Halim \& Syam Kusufi (2008) akuntansi sektor publik adalah suatu proses pengidentifikasian, pengukuran, pencatatan, dan pelaporan transaksi ekonomi (keuangan) dari suatu organisasi atau entitas publik seperti pemerintah, lembaga swadaya masyarakat (LSM), dan lain-lain yang dijadikan sebagai informasi dalam rangka mengambil keputusan ekonomi oleh pihak-pihak yang membutuhkan.

\section{Teori Efektivitas}

Kata efektif berasal dari bahasa inggris yaitu effective yang berarti berhasil, atau sesuatu yang dilakukan berhasil dengan baik.Menurut Nordiawan \& Hertianti (2010:161), efektivitas menunjukkan kesuksesan atau kegagalan dalam pencapaian tujuan sebuah kegiatan/kebijakan dimana ukuran efektivitas merupakan refleksi output. Jadi, efektivitas adalah ukuran untuk mengetahui tingkat keberhasilan kegiatan/aktivitas organisasi dalam pencapaian tujuan

\section{Pengertian Internal Control}

COSO (2013:3) mendefinisikan pengendalian internal sebagai berikut:"Internal control is a process, effected by an entity's board of directors, manage-ment, and other personnel, designed to provide reasonable assurance regarding the achievement of objectives relating to operations, reporting, and compliance". Menurut Yadyana (2009) pengendalian intern adalah suatu proses dari aktivitas operasional organisasi dan merupakan bagian integral dari proses manajemen, seperti perencanaan, pelaksanaan, dan pengendalian. 


\section{Tujuan Internal Control}

Menurut Mulyadi (2010:163) “Tujuan Sistem Pengendalian Internal” adalah :

1. Menjaga kekayaan organisasi.

2. Mengecek ketelitian dan keandalan data akuntansi.

3. Mendorong efesiensi.

4. Mendorong dipatuhinya kebijakan manajemen.

\section{Unsur-unsur Pengendalian Internal Control}

Sistem Pengendalian Intern Pemerintah (SPIP) adalah Sistem Pengendalian Intern yang harus diselenggarakan secara menyeluruh di lingkungan pemerintah pusat dan pemerintah daerah.Penyelenggaraan SPIP harus dilakukan secara menyeluruh dan terintegrasi dengan kegiatan operasional unit organisasi.Sesuai dengan Peraturan Pemerintah Nomor 60 Tahun 2008, Struktur Pengendalian Intern terdiri atas lima (5) unsur atau elemen yaitu:

1. Lingkungan Pengendalian

2. Penilaian Resiko

3. Kegiatan Pengendalian

4. Informasi dan Komunikasi

5. Pemantauan Pengendalian Intern

\section{Pengertian Kinerja}

Secara etimologis, kinerja adalah sebuah kata yang dalam bahasa Indonesia berasal dari kata dasar "kerja" yang menerjemahkan kata dari bahasa asing prestasi, bisa pula berarti hasil kerja. Sehingga pengertian kinerja dalam organisasi merupakan jawaban dari berhasil atau tidaknya tujuan organisasi yang telah ditetapkan.Menurut Moeheriono (2009:60) kinerja merupakan gambaran mengenai tingkat pencapaian pelaksanaan suatu program kegiatan atau kebijakan dalam mewujudkan sasaran, visi, misi organisasi yang dituangkan melalui perencanaan strategis suatu organisasi.

\section{Pengertian Pendapatan Asli Daerah}

Pengertianpendapatan asli daerah berdasarkan Undang-Undang Nomor 33 Tahun 2004 tentang Perimbangan Keuangan Antara Pusat dan Daerah Pasal 1ayat 18 bahwa "Pendapatan asli daerah, selanjutnya disebut PAD adalah pendapatan yang diperoleh daerah yang dipungut berdasarkan peraturan daerah sesuai dengan peraturan perundang-undangan". Menurut Azmi Hanif, dkk (2014)Pendapatan asli daerah adalah bagian dari pendapatan daerah yang bersumber dari potensi daerah itu sendiri yang dipungut berdasarkan peraturan daerah tersebut sesuai dengan peraturan perundang-undangan yang berlaku.

\section{Sumber-sumber pendapatan asli daerah}

Dalam upaya memperbesar peran pemerintah daerah dalam pembangunan, pemerintah daerah dituntut untuk lebih mandiri dalam membiayai kegiatan operasionah rumah tangganya.Berdasarkan hal tersebut dapat dilihat bahwa pendapatan daerah tidak dapat dipisahkan dengan belanja daerah, karena adanya saling terkait dan merupakan satu alokasi anggaran yang disusun dan dibuat untuk melancarkan roda pemerintahan daerah.Undang-Undang Nomor 32 Tahun 2004 tentang Pemerintah Daerah mengisyaratkan bahwa Pemerintah Daerah dalam mengurus rumah tangganya sendiri diberikan sumber-sumber pendapatan atau penerimaan keuangan Daerah untuk membiayai seluruh aktivitas dalam rangka pelaksanaan tugas-tugas pemerintah dan pembangunan untuk kesejahteraan masyarakat secara adil dan makmur.

\section{Penelitian Terdahulu}

SabinaDineshkumar, Priya Kogulacumar (2011) dengan judul Internal Control System and its impact on the Performance of the Sri Lanka Telecom limited in Jaffna District. Tujuan dari penelitian ini untukmempelajari sejauh mana sistem kontrol internal berpengaruh padakinerja perusahaan Telekomunikasi terbatas Sri Lanka di wilayah Jaffna.Metode penelitian yang digunakan metode deskriptif kualitatif. Hasil penelitian menunjukkan adahubungan yang kuat antara sistem pengendalian internal dankinerja perusahaan telekomunikasi terbatas Sri Lanka di wilayah Jaffna,serta internal kontrol jugaakan mengakibatkan kinerja organisasi yang tinggi dimasa depan. 
Vetty Panjaitan (2015) dengan judul Pengaruh Pengendalian Intern, Kompetensi Sumberdaya Manusia, Komitmen Organisasi dan Budaya Organisasi Terhadap Kinerja Bagian Keuangan Pada SKPD Kota Dumai.Tujuan dari penelitian ini untuk menguji pengaruh pengendalian intern, pengaruh kompetensi sumber daya manusia, pengaruh komitmen organisasi, dan pengaruh budaya organisasi terhadap kinerja bagian keuangan di pemerintah Kota Dumai.Metode penelitian yang digunakan metode analisis data, yaitu uji kualitas data dan uji asumsi klasik.Hasil penelitian membuktikan bahwa variabel pengendalian intern, kompetensi sumber daya manusia, komitmen organisasi berpengaruh terhadap kinerja SKPD bagian keuangan, serta budaya organisasi tidak berpengaruh terhadap kinerja SKPD bagian keuangan.

Rina Tresmawati (2012) dengan judul Pengaruh Efektifitas Pengendalian Intern Terhadap Kinerja Instansi Pemerintah Di Dinas Pendapatan Daerah Kota Bandung.Tujuan dari penelitian ini untuk mengetahui seberapa besar pengaruh efektifitas pengendalian intern terhadap kinerja Instansi pemerintah Kota Bandung.Metode penelitian yang digunakan metode deskriptif analitis.Hasil penelitian menyatakan bahwa pengendalian internal mempunyai pengaruh positif terhadap kinerja pada Dinas Pendapatan Daerah Kota Bandung.

Lissa Talib (2011) dengan judul Efektifitas Penerapan Pengendalian Intern (Internal Kontrol) Terhadap Kinerja Dinas Pendapatan Daerah Di Kota Manado.Tujuan dari penelitian ini untuk mengetahui efektifitas internal kontrol dan untuk peranan internal kontrol dalam menunjang efektifitas pada kinerja Dinas Pendapatan Daerah di Kota Manado.Metode yang digunakan metode deskriptif.Hasil penelitian diperoleh gambaran mengenai efektifitas penerapan pengendalian internal dan efektifitas penerimaan pajak daerah.

Cindy Bawiling (2015) dengan judul Evaluasi Penerapan Sistem Pengendalian Internal Pengeluaran Kas Pada Kantor Pengadilan Agama Tondano.Tujuan dari penelitian ini untuk mengetahui dan mengevaluasi kesesuaian sistem pengendalian internal pengeluaran kas yang diterapkan pada Kantor Pengadilan Agama Tondano dengan mekanisme pelaksanaan pembayaran atas beban anggaran belanja negara dalam konsep pengendalian internal menurut sistem akuntansi.Metode yang digunakan metode analisis deskriptif komporatif.Hasil penelitian diperoleh bahwa secara umum, sistem pengendalian internal terhadap pengeluaran kas yang dilakukan oleh Kantor Pengadilan Agama Tondano telah berlangsung dengan baik sesuai dengan peraturan yang berlaku.

\section{Jenis Penelitian}

\section{METODE PENELITIAN}

Jenis penelitian yang dipakai dalam penelitian ini adalah penelitian deskriptif.Menurut Arikunto (2010: 3) Penelitian deskriptif adalah penelitian yang dimaksudkan untuk menyelidiki keadaan, kondisi atau hal lain-lain yang sudah disebutkan, yang hasilnya dipaparkan dalam bentuk laporan penelitian.

\section{Jenis Data}

Data yang digunakan dalam penelitian ini adalah data kualitatif.Data kualitatif yang dibutuhkan dalam penelitian ini adalah sejarah Pendapatan Asli Daerah khususnya Kabupaten Minahasa Tenggara dan efektifitas dari internal control terhadap pelaksanaan administrasi pendapatan asli daerah.

\section{Sumber Data}

Sumber data terdiri atas:

1. Data Primer adalah data yang diperoleh dengan melakukan survey lapangan yang menggunakan semua metode pengumpulan data original.

2. Data Sekunder adalah data yang dikumpulkan oleh lembaga pengumpulan data dan dipublikasikan kepada masyarakat pengguna data. 
Sumber data yang digunakan dalam penelitian ini adalah data primer dan data sekunder.Data primer yang dibutuhkan merupaka data olahan dan diperoleh langsung dari DISPENDA, dan data sekunder merupakan data yang diambil dari bahan pustaka.

\section{Teknik Pengumpulan Data}

Dalam melengkapi hasil penelitian ini, maka penulis melakukan pengumpulan data dengan cara melakukan wawancara terhadap pegawai DISPENDA (Dinas Pendapatan Daerah Kabupaten Minahasa Tenggara), pengamatan lewat jasa internet, serta di perpustakaan, buku dan sumber-sumber lain yang relevan dengan data yang dibutuhkan.

\section{Metode Analisis}

1. Melakukan perbandingan antara Sistem Pengendalian Intern Pemerintah Nomor 60 Tahun 2008 dengan Sistem Pengendalian Intern yang ada dalam Dinas Pendapatan Daerah Kabupaten Minahasa Tenggara.

2. Menguji ketaatan aturan Sistem Pengendalian Intern dalam melaksanakan sistem dan prosedur penerimaan pajak daerah, formulir yang digunakan, dan pemisaha tugas.

3. Menguji efektivitas sistem pengendalian internal pada penerimaan pendapatan asli daerah.

\section{HASIL PENELITIAN DAN PEMBAHASAN}

\section{Prosedur Penerimaan Pendapatan Asli Daerah}

Tabel 4.3 Prosedur Penerimaan Pajak Hotel dan Restoran

\begin{tabular}{|c|c|c|c|}
\hline No & Pelaksana & Langkah & Keterangan \\
\hline \multirow[t]{2}{*}{1.} & \multirow[t]{2}{*}{ Wajib Pajak } & 1 & $\begin{array}{l}\text { Mengambil formulir pendaftaran yang telah } \\
\text { disediakan oleh DISPENDA }\end{array}$ \\
\hline & & 2 & $\begin{array}{l}\text { Mengisi dan melengkapi formulir pendaftaran } \\
\text { dengan jelas, lengkap dan benar }\end{array}$ \\
\hline 2. & Pendataan & 3 & Pemeriksaan oleh petugas pendataan \\
\hline \multirow[t]{6}{*}{3.} & \multirow[t]{6}{*}{ Administrasi } & 4 & $\begin{array}{l}\text { Dikeluarkan NPWPD } \\
\text { nomor urut pendaftaran }\end{array}$ \\
\hline & & 5 & $\begin{array}{l}\text { Keluar surat ketetapan pajak hotel dan restoran } \\
\text { untuk wajib pajak }\end{array}$ \\
\hline & & 6 & $\begin{array}{l}\text { Mengisi SPTD dengan jelas dan lengkap } \\
\text { ditandatangani oleh wajib pajak atau kuasanya }\end{array}$ \\
\hline & & 7 & Mengisi surat ketetapan pajak hotel dan restoran \\
\hline & & 8 & $\begin{array}{l}\text { Setelah selesai melakukan pengisian dokumen- } \\
\text { dokumen yang ada, dikeluarkan nota perhitungan } \\
\text { pajak }\end{array}$ \\
\hline & & 9 & Mengisi nota perhitungan pajak \\
\hline \multirow[t]{4}{*}{4.} & \multirow{4}{*}{$\begin{array}{l}\text { Bendahara } \\
\text { Penerima }\end{array}$} & 10 & Pembayaran dilakukan secara tunai \\
\hline & & 11 & $\begin{array}{l}\text { Setelah pembayaran didapat tanda } \\
\text { pembayaran, terdapat } 3 \text { (tiga) rangkap } \\
\text { pembayaran : } \\
\text { a. Lembar } 1 \text { : Untuk Wajib Pajak } \\
\text { b. Lembar 2: Untuk Bidang PAD } \\
\text { c. Lembar 3 : Untuk Bidang Pembukuan }\end{array}$ \\
\hline & & 12 & $\begin{array}{l}\text { Pembayaran biasa dilakukan melalui bank dengan } \\
\text { mempersiapkan deposit slip }\end{array}$ \\
\hline & & 13 & $\begin{array}{l}\text { Pembayaran secara tunai dan lunas dengan } \\
\text { mendapat bukti penyetoran dari bank }\end{array}$ \\
\hline
\end{tabular}




\begin{tabular}{|l|l|c|l|}
\hline No & Pelaksana & Langkah & \multicolumn{1}{|c|}{ Keterangan } \\
\hline & \multirow{2}{*}{} & 14 & $\begin{array}{l}\text { Setelah dilunasi pembayaran dikeluarkan surat } \\
\text { keterangan fiscal }\end{array}$ \\
\cline { 3 - 5 } & & 15 & Bukti pemenuhan kewajiban membayar pajak \\
\cline { 3 - 5 } & & 16 & Ditandatangani oleh Kepala Dinas Pendapatan \\
\cline { 3 - 5 } & & 17 & Dicatat dalam buku penerimaan \\
\hline 5 & Kas Daerah & 18 & $\begin{array}{l}\text { Setelah itu, pembayaran pajak disetor ke Kas } \\
\text { Daerah }\end{array}$ \\
\hline
\end{tabular}

Sumber: Data olahan dari Peraturan Daerah No. 5 Tahun 2013 tentang Penerimaan PAD.

Dari formulir yang digunakan dalam penyetoran Pajak Hotel dan Restoran telah berisikan informasi: nomor dan tahun Surat Setoran Pajak Daerah (SSPD), nama badan usaha, nama dan alamat serta NPWPD pemilik usaha, uraian pajak yang disetor, dan verifikasi petugas dinas (Bendahara Penerima dan Kabid/Kasie PAD). Hal ini menunjukkan formulir telah berisikan informasi yang handal, pendelegasian wewenang dan tanggungjawab yang tepat.

Tabel 4.4Prosedur Penerimaan Pajak Bea Perolehan Hak atas Tanah dan Bangunan (BPHTB)

\begin{tabular}{|c|c|c|c|}
\hline No & Pelaksana & Langkah & Keterangan \\
\hline \multirow[t]{2}{*}{1.} & \multirow[t]{2}{*}{ Wajib Pajak } & 1 & $\begin{array}{l}\text { Mengambil formulir pendaftaran yang telah } \\
\text { disediakan oleh DISPENDA }\end{array}$ \\
\hline & & 2 & $\begin{array}{l}\text { Mengisi dan melengkapi formulir pendaftaran } \\
\text { dengan jelas, lengkap dan benar }\end{array}$ \\
\hline 2. & Pendataan & 3 & Pemeriksaan oleh petugas pendataan \\
\hline \multirow[t]{6}{*}{3.} & \multirow[t]{6}{*}{ Administrasi } & 4 & $\begin{array}{l}\text { Dikeluarkan NPWPD berdasarkan pengisian } \\
\text { nomor urut pendaftaran }\end{array}$ \\
\hline & & 5 & $\begin{array}{l}\text { Keluar surat ketetapan pajak Bea Perolehan Hak } \\
\text { atas Tanah dan Bangunan (BPHTB) untuk wajib } \\
\text { pajak }\end{array}$ \\
\hline & & 6 & $\begin{array}{l}\text { Mengisi SPTD dengan jelas dan lengkap } \\
\text { ditandatangani oleh wajib pajak atau kuasanya }\end{array}$ \\
\hline & & 7 & $\begin{array}{l}\text { Mengisi surat ketetapan pajak Bea Perolehan } \\
\text { Hak atas Tanah dan Bangunan (BPHTB) }\end{array}$ \\
\hline & & 8 & $\begin{array}{l}\text { Setelah selesai melakukan pengisian dokumen- } \\
\text { dokumen yang ada, dikeluarkan nota perhitungan } \\
\text { pajak }\end{array}$ \\
\hline & & 9 & Mengisi nota perhitungan pajak \\
\hline \multirow[t]{5}{*}{4.} & \multirow{5}{*}{$\begin{array}{l}\text { Bendahara } \\
\text { Penerima }\end{array}$} & 10 & Pembayaran dilakukan secara tunai \\
\hline & & 11 & $\begin{array}{l}\text { Setelah pembayaran didapat tanda bukti } \\
\text { pembayaran, terdapat } 3 \text { (tiga) rangkap bukti } \\
\text { pembayaran : } \\
\text { a. Lembar } 1 \text { : Untuk Wajib Pajak } \\
\text { b. Lembar 2 : Untuk Bidang PAD } \\
\text { c. Lembar } 3 \text { : Untuk Bidang Pembukuan }\end{array}$ \\
\hline & & 12 & $\begin{array}{l}\text { Pembayaran biasa dilakukan melalui bank } \\
\text { dengan mempersiapkan deposit slip }\end{array}$ \\
\hline & & 13 & $\begin{array}{l}\text { Pembayaran secara tunai dan lunas dengan } \\
\text { mendapat bukti penyetoran dari bank }\end{array}$ \\
\hline & & 14 & $\begin{array}{l}\text { Setelah dilunasi pembayaran dikeluarkan surat } \\
\text { keterangan fiscal }\end{array}$ \\
\hline
\end{tabular}




\begin{tabular}{|l|l|c|l|}
\hline No & Pelaksana & Langkah & \multicolumn{1}{c|}{ Keterangan } \\
\hline & & 15 & Bukti pemenuhan kewajiban membayar pajak \\
\cline { 3 - 4 } & & 16 & Ditandatangani oleh Kepala Dinas Pendapatan \\
\cline { 3 - 4 } & & 17 & Dicatat dalam buku penerimaan \\
\hline 5. & Kas Daerah & 18 & $\begin{array}{l}\text { Setelah itu, pembayaran pajak disetor ke Kas } \\
\text { Daerah }\end{array}$ \\
\hline
\end{tabular}

Sumber: Data olahan dari Peraturan Daerah No. 5 Tahun 2013 tentang Penerimaan PAD

Dari formulir yang digunakan dalam penyetoran Pajak Bea Perolehan Hak atas Tanah dan Bangunan (BPHTB) telah berisikan informasi: nomor bukti SSPD-BPHTB, nama dan alamat serta NPWPD wajib pajak, uraian pajak yang disetor, uraian penghitungan BHPTB dan jumlah setoran pajak, keterangan rekening kas daerah, verifikasi petugas dinas. Hal ini menunjukkan formulir telah berisikan informasi yang handal, pendelegasian wewenang dan tanggungjawab yang tepat.

Tabel 4.5 Prosedur Penerimaan Pajak Bumi dan Bangunan

\begin{tabular}{|c|c|c|c|}
\hline No & Pelaksana & Langkah & Keterangan \\
\hline \multirow[t]{2}{*}{1.} & \multirow[t]{2}{*}{ Wajib Pajak } & 1 & $\begin{array}{l}\text { Mengambil formulir pendaftaran yang telah } \\
\text { disediakan oleh DISPENDA }\end{array}$ \\
\hline & & 2 & $\begin{array}{l}\text { Mengisi dan melengkapi formulir pendaftaran } \\
\text { dengan jelas, lengkap dan benar }\end{array}$ \\
\hline 2. & Pendataan & 3 & Pemeriksaan oleh petugas pendataan \\
\hline \multirow[t]{6}{*}{3.} & \multirow[t]{6}{*}{ Administrasi } & 4 & $\begin{array}{l}\text { Dikeluarkan NPWPD berdasarkan pengisian } \\
\text { nomor urut pendaftaran }\end{array}$ \\
\hline & & 5 & $\begin{array}{l}\text { Keluar surat ketetapan pajak Bumi dan } \\
\text { Bangunan untuk wajib pajak }\end{array}$ \\
\hline & & 6 & $\begin{array}{l}\text { Mengisi SPTD dengan jelas dan lengkap } \\
\text { ditandatangani oleh wajib pajak atau kuasanya }\end{array}$ \\
\hline & & 7 & $\begin{array}{l}\text { Mengisi surat ketetapan pajak Bumi dan } \\
\text { Bangunan }\end{array}$ \\
\hline & & 8 & $\begin{array}{l}\text { Setelah selesai melakukan pengisian dokumen- } \\
\text { dokumen yang ada, dikeluarkan nota } \\
\text { perhitungan pajak }\end{array}$ \\
\hline & & 9 & Mengisi nota perhitungan pajak \\
\hline \multirow[t]{7}{*}{4.} & \multirow{7}{*}{$\begin{array}{l}\text { Bendahara } \\
\text { Penerima }\end{array}$} & 10 & Pembayaran dilakukan secara tunai \\
\hline & & 11 & $\begin{array}{l}\text { Setelah pembayaran didapat tanda bukti } \\
\text { pembayaran, terdapat } 3 \text { (tiga) rangkap bukti } \\
\text { pembayaran: } \\
\text { a. Lembar } 1: \text { Untuk Wajib Pajak } \\
\text { b. Lembar 2: Untuk Bidang PAD } \\
\text { c. Lembar 3: Untuk Bidang Pembukuan }\end{array}$ \\
\hline & & 12 & $\begin{array}{l}\text { Pembayaran biasa dilakukan melalui bank } \\
\text { dengan mempersiapkan deposit slip }\end{array}$ \\
\hline & & 13 & $\begin{array}{l}\text { Pembayaran secara tunai dan lunas dengan } \\
\text { mendapat bukti penyetoran dari bank }\end{array}$ \\
\hline & & 14 & $\begin{array}{l}\text { Setelah dilunasi pembayaran dikeluarkan surat } \\
\text { keterangan fiscal }\end{array}$ \\
\hline & & 15 & Bukti pemenuhan kewajiban membayar pajak \\
\hline & & 16 & Ditandatangani oleh Kepala Dinas Pendapatan \\
\hline
\end{tabular}




\begin{tabular}{|l|l|c|l|}
\hline No & \multicolumn{1}{|c|}{ Pelaksana } & Langkah & \multicolumn{1}{c|}{ Keterangan } \\
\hline & & 17 & Dicatat dalam buku penerimaan \\
\hline 5. & Kas Daerah & 18 & $\begin{array}{l}\text { Setelah itu, pembayaran pajak disetor ke Kas } \\
\text { Daerah }\end{array}$ \\
\hline
\end{tabular}

Sumber: Data olahan dari Peraturan Daerah No. 5 Tahun 2013 tentang Penerimaan PAD.

Dari formulir yang digunakan dalam penyetoran Pajak Pajak Bumi dan Bangunan yaitu Surat Pemberitahuan Pajak Daerah Terutang telah berisikan informasi: nama dan luas objek pajak, uraian penghitungan PBB terutang tanggal jatuh tempo dan tempat pembayaran. Sedangkan Surat Setoran Pajak Daerah (SSPD) berikan informasi: lokasi pembayaran, jumlah setoran pajak, nama dan lokasi obyek pajak, nomor objek pajak, verifikasi petugas bank/Bendaha Penerima. Hal ini menunjukkan formulir telah berisikan informasi yang handal, pendelegasian wewenang dan tanggungjawab yang tepat.

\section{Sistem Pengendalian Intern Penerimaan PAD}

Dalam penelitian ini penulis melakukan wawncara sebagai instrumen untuk memperoleh gambaran sejauh mana efektifitas penerapan Pengendalian Intern. Dalam wawancara atas Pengendalian Intern mendasarkan pada Peraturan Pemerintah RI Nomor 60 tahun 2008 tentang Sistem Pengendalian Intern Pemerintah (SPIP). Hasil pengujian SPIP meliputi lima unsur sebagai berikut:

1. Lingkungan Pengendalian

2. Penilaian Risiko

3. Kegiatan Pengendalian

4. Informasi dan Komunikasi

5. Pemantauan Pengendalian Intern

\section{Pembahasan}

\section{Evaluasi Sistem Pengendalian Intern atas Prosedur Penerimaan PAD}

Evaluasi Sistem Pengendalian Internatas prosedur penerimaan PAD oleh penulis berfokus pada evaluasi penerapan sistem pengendalian intern atas penerimaan Pajak Hotel dan Restoran, Pajak Bea Perolehan Hak atas Tanah, dan Pajak Bumi dan Bangunan, adalah sebagai berikut:

1. Pemisahan Tugas yang Cukup

Prosedur penerimaan Pajak Daerah (Pajak Hotel dan Restoran, Pajak Bea Perolehan Hak atas Tanah/BPHTB, dan Pajak Bumi dan Bangunan) dimulai dengan pengisian kelengkapan formulir pendaftaran oleh Wajib Pajak dan dilakukan pemeriksaan oleh Petugas Pendataan, pembayaran pajak secara tunai diadministrasikan dan dicatat oleh Bendahara Penerima dan setiap hari menyetorkan ke Kas Daerah atau penyetoran langsung oleh Wajib Pajak melalui Bank. Prosedur penerimaan Pajak Daerah tersebut telah mencermin dengan adanya pemisahan tugas yang cukup yaitu pemisahan tugas penerima pajak oleh bagian Bendahara Penerima dan/atau Bank, pencatatan pada bagian Administrasi, dan penyimpanan pada bagian Kas Daerah.Namun masih ditemukan adanya kelemahan yaitu penerimaan pajak dilakukan selain Bank juga oleh Bendahara Penerima.Sebaiknya setiap penerimaan pajak hanya dilakukan pada pihak Bank, karena setiap penerimaan pajak oleh Bendahara Penerima diharuskan setiap hari langsung menyetorkan ke bank.

2. Formulir

Formulir yang digunakan dalam penyetoran pajak, dapat diketahui adanya pengendalian intern, adalah sebagai berikut:

a) Formulir pendaftaran wajib pajak, berisikan: nama pemilik, nomor, tanggal, keterangan, jabatan, alamat, tanda tangan pengolah dan petugas.

b) Formulir SPT (Surat Pemberitahuan) untuk wajib pajak, berisikan: nomor SPT, tahun, NPWPD, keterangan, nama, tanggal, tanda tangan wajib pajak dan petugas.

c) Formulir setoran pajak daerah, berisikan: jenis pajak dan retribusi, merek usaha, alamat, nama pemilik, klasifikasi pajak, tanda tangan dan tanggal. 
d) Formulir Tanda Bukti Pembayaran, berisikan: nomor bukti, jumlah, nama pembayar, alamat, NPWPD, tujuan pembayaran, kode rekening, tanggal diterima, tanda tangan Bendahara Penerima dan tanda tangan Penyetor.

e) Formulir Surat Ketetapan pajak Daerah (SKPD), berisikan: nomor urut, masa, tahun, nama, alamat, uraian pajak daerah, jumlah, catatan, tanda tangan kepala dinas dan wajib pajak.

Dari isi formulir yang digunakan sebagai penyetoran pajak pada Dinas Pendapatan Daerah Kabupaten Minahasa Tenggara tersebut di atas telah memadai.Hal ini tercermin dari sistem informasi telah memuat informasi yang handal.Namun masih ditemukan adanya kelemahan yaitu formulir pendaftaran wajib pajak hanya satu rangkap untuk Petugas Pendataan. Sebaiknya dibuatkan rangkap dua yaitu lembar ke satu asli untuk petugas pendataan dan lembar ke dua untuk wajib pajak, hal ini dilakukan agar wajib pajak memiliki bukti pendaftaran sebagai wajib pajak.

3. Pendelegasian Wewenang dan Tanggung Jawab yang Tepat

Pendelegasian wewenang dan tanggung jawab pada Dinas Pendapatan Daerah Kabupaten Minahasa Tenggara telah memadai.Hal ini tercermin dari tanggung jawab yang diberikan dan dokumen yang terkait penerimaan pajak daerah yang jelas dan terkoordinir.Sistem yang baik harus ada pembagian wewenang dan tanggung jawab yang jelas, dokumen yang memadai, dan prosedur yang yang mencapai tujuannya.

Sedangkan pelaksanaan tugas pokok dalam organisasi, dapat diuraikan dengan mendasarkan pada Peraturan Pemerintah RI Nomor 60 tahun 2008 tentang Sistem Pengendalian Intern Pemerintah (SPIP), meliputi lima unsur sebagai berikut:

1. Lingkungan Pengendalian

Lingkungan pengendalian pada Dinas Pendapatan Daerah Kabupaten Minahasa Tenggara telah memadai guna mendorong dipatuhinya kebijakan manajemen dalam menjalankan organisasi secara efektif dan efisien.

2. Penilaian Risiko

Pelaksanaan penilaian risiko oleh Dinas Pendapatan Daerah Kabupaten Minahasa Tenggara telah memadai guna mencapai tujuan organisasi.Hal ini tercermin telah optimalnya daya guna baik dari sumber daya manusia, sistem informasi, dan pertumbuhan yang cepat dalam hal pemungutan pajak daerah.

3. Kegiatan Pengendalian

Kegiatan pengendalian pada Dinas Pendapatan Daerah Kabupaten Minahasa Tenggara telah memadai guna mencapai tujuan yang dapat memberikan keyakinan bahwa petunjuk yang dibuat telah dilaksanakan.

4. Informasi dan Komunikasi

Sistem informasi dan komunikasi pada Dinas Pendapatan Daerah Kabupaten Minahasa Tenggara telah memadai guna mencapai tujuan dalam hal menyediakan, memanfaatkan, mengelola, dan memperbarui sistem informasi secara terus menerus.Hal ini tercermin dari informasi pada Dinas Pendapatan Daerah Kabupaten Minahasa Tenggara mulai dari entry data-data yang berhubungan dengan wajib pajak, dan jumlah pajak telah dilakukan. Komunikasi yang dilakukan terhadap wajib pajak biasanya dilakukan secara langsung oleh petugas dinas atau alat komunikasi tidak langsung seperti telepon.

5. Pemantauan Pengendalian Intern

Pemantauan dilakukan oleh Dinas Pendapatan Daerah Kabupaten Minahasa Tenggara telah memadai guna mencapai tujuan mendeteksi kemungkinan adanya penyimpangan dalam penerimaan pendapatan daerah oleh wajib pajak. Penyimpangan tersebut merupakan faktor resiko yang dapat merugikan Dinas Pendapatan Daerah Kabupaten Minahasa Tenggara maupun wajib pajak.Hal ini tercermin dari Dinas Pendapatan Daerah Kabupaten Minahasa Tenggara secara berkesinambungan melakukan evaluasi terhadap semua kegiatan penerimaan pendapatan daerah, dengan tujuan untuk mengetahui kelemahan yang ada dalam penerimaan pendapatan daerah Kabupaten Minahasa Tenggara, sehingga dapat diupayakan pengendalian intern yang lebih baik. 


\section{Kesimpulan}

\section{PENUTUP}

Berdasarkan hasil penelitian dan pembahasan yang dilakukan maka dapat disimpulkan bahwa Penerapan Sistem Pengendalian Intern (Intern Control) terhadap kinerja Dinas Pendapatan Daerah Kabupaten Minahasa Tenggara Provinsi Sulawesi Utara telah "efektif", Hal ini tercermin antara lain:

1. Penerapan sistem pengendalian intern atas penerimaan PAD telah memadai karena telah dilakukan pemisahan tugas yang cukup, formulir yang digunakan dalam penyetoran pajak telah memuat informasi yang handal, tanggung jawab yang diberikan dan dokumen yang terkait penerimaan pajak daerah yang jelas dan terkoordinir.

2. Penerapan sistem pengendalian intern atas realisasi penerimaan PAD telah memadai karena pencapaian target penerimaan PAD tahun 2015 sudah berjalan efektif, sedangkan pelaksanaan tugas pokok dalam organisasi yang mendasarkan pada Peraturan Pemerintah RI Nomor 60 tahun 2008 tentang Sistem Pengendalian Intern Pemerintah (SPIP) telah memadai.

\section{Saran}

Sejalan dengan hasil uraian pembahasan dan kesimpulan sebagaimana diuraikan di atas, maka Penulis dapat menyampaikan saran sebagai berikut:

1. Setiap pegawai agar diwajibkan menandatangani Pakta Integritas dan Aturan Perilaku Pegawai.

2. Setiap penerimaan pajak agar dilakukan hanya pihak Bank Penerima, hal ini dilakukan untuk menghindari terjadinya penyimpangan.

3. Formulir pendaftaran wajib pajak agar dibuatkan rangkap dua yaitu lembar ke satu asli untuk petugas pendataan dan lembar ke dua untuk wajib pajak, hal ini dilakukan agar wajib pajak memiliki bukti pendaftaran sebagai wajib pajak.

4. Setiap pegawai agar diwajibkan menandatangani Pakta Integritas dan Aturan Perilaku Pegawai.

5. Menyelenggarakan penilaian resiko secara rutin dengan menyusunFraud Control Plan sebagai bentuk rencana pengendalian terhadap penyimpangan penerimaan PAD.

6. Mengaktifkan dan memaksimalkan Satgas SPIP (Sistem Pengendalian Internal Pemerintah).

7. Melaksanakan penyusunan pemetaan atas potensi PAD di Kabupaten Minahasa Tenggara.

\section{DAFTAR PUSTAKA}

Azmi Hanif, Dkk., 2014, Pendapatan Asli Daerah Dan Pendapatan Daerah Lainnya.Universitas Sultan Ageng Tirtayasa : Banten. Tanggal Akses: 26 Februari 2016. http://www.academia.edu/7169986/ Pendapatan Asli Daerah Dan_Pendapatan_Daearah_Lainnya.

Abdul Halim \& Syam Kusufi. 2008. Akuntansi Sektor Publik. Jakarta: Penerbit Salemba Empat

Andi.Moeheriono. 2009. Pengkuran Kinerja Berbasis Kompetensi. Bogor: Ghalia Indonesia.

Arikunto, S. 2010. Prosedur penelitian : Suatu Pendekatan Praktik. (Edisi Revisi). Jakarta : Rineka Cipta

BPKP, 2008.Online : Peraturan Pemerintah Republik Indonesia Nomor 60 Tahun 2008 Tentang Sistem Pengendalian Intern Pemerintah. Diakses Tanggal : 16 Februari 2016 . http://www. itjen. depkes. go. id/ public/ upload/ unit/ pusat/ files/ PeraturanPemerintah/ PP60Tahun2008 ttg SPIP.pdf

Bawiling, Cindy, 2015, Online: Evaluasi Penerapan Sistem Pengendalian Internal Pengeluaran Kas Pada Kantor Pengadilan Agama Tondano, ISSN2303-11. http: // ejournal .unsrat. ac. id/ index. php/ emba/ article/view/9533/9113

Bastian, Indra. 2010. Akuntansi Sektor Publik Suatu Pengantar Edisi Ketiga. Penerbit Erlangga: Jakarta.

COSO, 2013, Internal Control - Integrated Framework : Executive Summary, Durham, North Carolina, May 2013

Dineshkumar ,Sabina and Kogulacumar,Priya, 2011, "Internal Control System and its impact on the Performance of the Sri Lanka Telecom limited in Jaffna District". Faculty of management studies \& commerce, University of Jaffna, Sri Lanka, ISSN:2319-7900. http: // ijact .org/ volume2issue6/IJ0260029.pdf 
Depkeu.2004, Online : Undang - Undang Republik Indonesia Nomor 32 Tahun 2004 Tentang Pemerintah Daerah. Diakses Tanggal : 20 ebruari 2016. http://www.sjdih.depkeu.go.id/fulltext/2004/32TAHUN2004UU.htm

Ismail. 2010. Akuntansi Bank. Jakarta: Penerbit Kencana

Mulyadi. 2010. Sistem Akuntansi. Jakarta: Salemba Empa

Nordiawan, Deddi dan Hertianti, Ayuningtyas. 2010. Akuntansi Sektor Publik. Edisi Kedua. Jakarta: Salemba Empat.

Panjaitan, Vetty, 2015, Pengaruh Pengendalian Intern, Kompetensi Sumberdaya Manusia, Komitmen Organisasi dan Budaya Organisasi Terhadap Kinerja Bagian Keuangan Pada SKPD Kota Dumai. Universitas Riau Pekanbaru. Jom FEKON Vol. 2 No. 2 Oktober 2015, Diakses Tanggal: 25 Februari 2016. https: //www.google.com/url?sa $t \& r c t=j \& q=\& e s r c=s \& s o u r c e=$ web \&cd=1\&cad=rja\&uact=8\&ved=0ahUKEwjfqLvwnaLLAhWIGY4KHd3.

Rina Tresnawati, 2012, Pengaruh Efektifitas Pengendalian Intern Terhadap Kinerja Instansi Pemerintah Di Dinas Pendapatan Daerah Kota Bandung. Universitas Widyatama : Bandung. ISBN : 978-602-17225-0-3. Diakses Tanggal : 24 Februari 2016. http:// repository. widyatama. ac. id/xmlui/bitstream/handle/123456789/2424/CONTENT\%20RINA.pdf?sequence5

Slideshare.net, 2013, Online: Undang - Undang Republik Indonesia Nomor 33 Tahun 2004 Tentang Perimbangan Keuangan Antara Pemerintah Pusat Dan Pemerintah Daerah. Diakses Tanggal : 23 Februari 2016. http://www.slideshare.net/perencanakota/uu-33tahun2004-perimbangankeuangan-pusat-daerah

Talib Lissa. (2011). Efektifitas Penerapan Pengendalian Intern (Internal Control) Terhadap Kinerja Dinas Pendapatan Daerah Di Kota Manado.Universitas Sam Ratulangi Manado.

Yadyana, I Ketut. 2009, Pengaruh Kualitas Jasa Auditor Internal Terhadap Efektivitas Pengendalian Intern Pada Hotel Berbintang Empat Dan Lima Di Bali, Jurnal Ilmiah Akuntansi Dan Bisnis Vol. 4, No. 1 Publisher: Jurnal Ilmiah Akuntansi Dan Bisnis. http://id.portalgaruda.org lindex.php?page $=2 \& \mathrm{ipp}=10 \& \mathrm{ref}=$ search $\&$ mod $=$ document $\&$ select $=$ title $\& q=$ pengendalian + inte $\underline{\text { rn\&button=Search }+ \text { Document }}$ 